\title{
Working Capital Management Practices
}

\author{
CS Gowtham, S. Praveen Kumar, A.Kamal
}

\begin{abstract}
VJ Engineers is one of the popular organizations in Chennai. Seeing the good opportunity to study financial systems and practices of VJ Engineers, it is relatively important to take up assignment on 'WORKING CAPITAL MANAGEMENT IN VJ ENGINEERS'. During the project work, it is being analyzed the working capital position of this organization. [1],[3],[5] Decisions relating to working capital and short term financing are referred to as working capital management. These involve managing the relationship between a firm's short-term assets and its short-term liabilities. The goal of Working capital management is to ensure that the firm is able to continue its operations and that it has sufficient money flow to satisfy both maturing short-term debt and upcoming operational expenses.The study of working capital management is very helpful for the organisation to know its liquidity position. The study is relevant to the organization to know the day to day expenditure. This study is relevant to give an idea to utilise the current assets. This study is also relevant to the student as they can use it as a reference. This report will help in conducting further research. Other researcher can use this project as secondary data uncovering of PDA incorporation in effects on police reports.
\end{abstract}

Keywords : management,capital,inventors

\section{INTRODUCTION}

Whatever may be the organization, working capital plays an important role, as the company needs capital for its day to day expenditure. Thousands of companies fail each year due to poor working capital management practices. Entrepreneurs often don't account for short term disruptions to cash flow and are forced to close their operations.

In simple term, working capital is an excess of current assets over the current liabilities. Good working capital management reveals higher returns of current assets than the current liabilities to maintain a steady liquidity position of a company. Otherwise, working capital is a requirement of funds to meet the day to day working expenses. So a proper way of management of working capital is highly essential to ensure a dynamic stability of the financial position of an organization.Seeing the good opportunity to study financial systems and practices of VJ Engineers, it is relatively important take up internship assignment on 'Working Capital Management in VJ Engineers'. During the project work, it is being analyzed the working capital position of this organization. Decisions relating to working capital and short term financing are referred to as working capital

Revised Manuscript Received on July 22, 2019.

CS.Gowtham, Department of MBA, Bharath Institute of Higher Education and Research, Tamilnadu, India. Email: chakravins@gmail.com

Dr.S.Praveen Kumar, Department of MBA, Bharath Institute of Higher Education and Research, Tamilnadu, India. Email: praveenkumar.mba@bharathuniv.ac.in

Dr.A.Kamal, Department of EEE, Bharath Institute of Higher Education and Research, Tamilnadu, India. Email: ak2-anvi@yahoo.co.in management. These involve managing the relationship between a firm's short-term assets and its short-term liabilities. The goal of Working capital management is to ensure that the firm is able to continue its operations and that it has sufficient money flow to satisfy both maturing short-term debt and upcoming operational expenses. [2 ], [ 4],[6]

Working capital management deals with maintaining the levels of working capital to optimum, because if a concern has inadequate opportunities and if the working capital is more than required then the concern will lose money in the form of interest on the blocked funds. Therefore working capital management plays a very important role in the profitability of a company. And also due to heavy competitions among different organization's it is now compulsory to look after working capital[7],[ 9], ,11]

The selection of topic is a crucial factor in any research study. There should be newness and it should give maximum scope to explore the ideas from different angles.In present day due to increase in competition, working capital is becoming necessary for the organisation. It is that part of capital which is necessary to undertake day to day expenditure of the business organization. Whatever may be the organization, working capital plays an important role, as the company needs capital for its day to day expenditure. Thousands of companies fail each year due to poor working capital management practices. Entrepreneurs often don't account for short term disruptions to cash flow and are forced to close their operations. Working capital is the fund invested by a firm in current assets. [8],[ [10], ,12]

Now in a cut throat competitive era where each firm competes with each other to increase their production and sales, holding of sufficient current assets have become mandatory as current assets include inventories and raw materials which are required for smooth production runs. Holding of sufficient current assets will ensure smooth and uninterrupted production but at the same time, it will consume a lot of working capital. Here creeps the importance and need of efficient working capital management. After due to consultation with the external guide /internal guide, the topic was finalized and titled as-"A Study on Working Capital Management in VJ Engineers, Chennai" [13], [15] ,[ 17]

\section{OBJECTIVES}

\section{A. Primary objectives}

To study the working capital management of VJ Engineers

\section{B. Secondary Objectives}

To evaluate whether the speculation of VJ Engineers current resources are adequate, contrasted with the situation of current liabilities 
- To study the current arrangement of working capital administration including money the executives, make back the initial investment investigation and influences independently

- To find and recommend, at every possible opportunity, available resources of lessening the present degrees of stock by improving present frameworks and office working technique. [14],[16], [18]

- To decrease inertness of money and give, productive working capital through keeping up need based money balance without imperiling the liquidity needs of the business. [19],[21],[23]

- To study the gainfulness proportions and discover the adjustments in benefit because of changes in credit measures, credit period, and money markdown.

- To decide the security, liquidity and benefit of the organization with the assistance of proportions identified with working capital administration and examinations them with proposals.

\section{RESEARCH METHODOLOGY}

Research philosophy is an orderly methodology in the executives research to accomplish pre-characterized targets. It causes a specialist to control over the span of research work. Principles and procedures expressed in research technique spare time and work of the specialist as scientist realize how to continue to lead the investigation according to the target.The location for study was selected as the VJ Engineers, Chennai.

\section{RESEARCH DESIGN}

\section{SOURCES OF DATA COLLECTION}

\section{Secondary data collection}

The optional information are those which have effectively gathered and put away. Optional information effectively get those auxiliary information from records, diaries, yearly reports of the organization and so on. It will spare the time, cash and endeavors to gather the information. Auxiliary information additionally made accessible through exchange magazines, yearly reports, books and so on. [20],[22], [24]

This task is based optional information gathered through yearly reports of the association. The information accumulation was gone for investigation of working capital administration of the organization.

Study is made by gathering data for the budgetary years 2013, 2014, 2015, 2016, and 2017

- The information in regards to the money the executives were gathered from the fund division of the organization.
-The gathered information are determined and dissected utilizing different ostensible scales.

- Based on the different examination recommendations were given.

\section{DATA ANALYSIS AND INTERPRETATION}

TABLE :1 CURRENT ASSETS RATIO

\begin{tabular}{|l|l|l|l|}
\hline Year & Current assets & Current liabilities & Current asset ratio \\
\hline 2013 & 56132794.31 & 7929635.83 & 7.08 \\
\hline 2014 & 78987183.77 & 8690005.75 & 9.09 \\
\hline 2015 & 99628120.4 & 14066553.76 & 7.08 \\
\hline 2016 & 119900229.5 & 93253414.74 & 1.29 \\
\hline 2017 & 136700747.4 & 98234418.41 & 1.39 \\
\hline
\end{tabular}

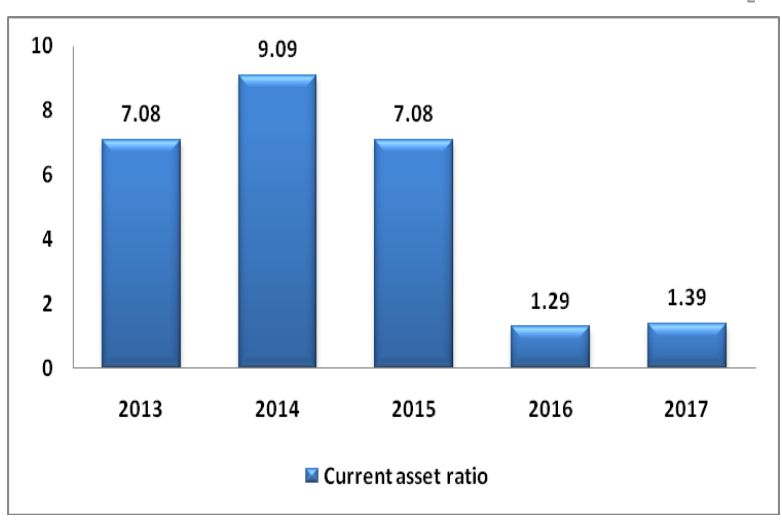

Fig:1 CURRENT ASSETS RATIO

TABLE 2 LIQUID RATIO

\begin{tabular}{|l|l|l|l|}
\hline Year & Liquid assets & Current liabilities & Liquid ratio \\
\hline 2013 & 26600196.41 & 7929635.83 & 3.35 \\
\hline 2014 & 42350445.3 & 8690005.75 & 4.87 \\
\hline 2015 & 61083326.19 & 14066553.76 & 4.34 \\
\hline 2016 & 70825254.15 & 932534414.74 & 0.76 \\
\hline 2017 & 83676938.44 & 98234418.41 & 0.85 \\
\hline
\end{tabular}



ISSN: 2277-3878, Volume-8, Issue-2S8, August 2019

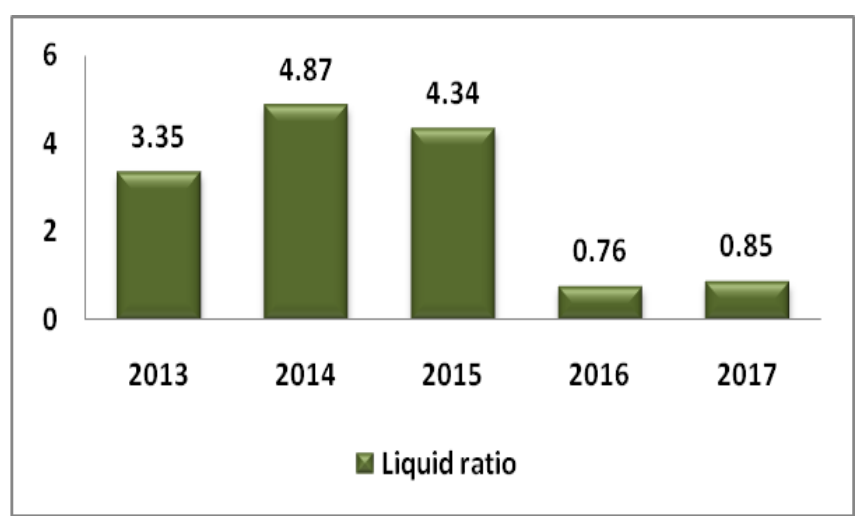

Fig: 2 LIQUID RATIO

TABLE 3 NET PROFIT RATIO

\begin{tabular}{|l|l|l|l|}
\hline Years & Net Profit & Net Sales & Net Profit Ratio \\
\hline 2013 & $30,854,152.38$ & $124,612,231.32$ & 0.248 \\
\hline 2014 & $102,250,057.89$ & $148,745,150.78$ & 0.687 \\
\hline 2015 & $81,117,232.38$ & $142,008,057.06$ & 0.571 \\
\hline 2016 & $92,429,095.13$ & $148,703,146,00$ & 0.622 \\
\hline 2017 & $104,283,901.36$ & $147,856,830.33$ & 0.705 \\
\hline
\end{tabular}

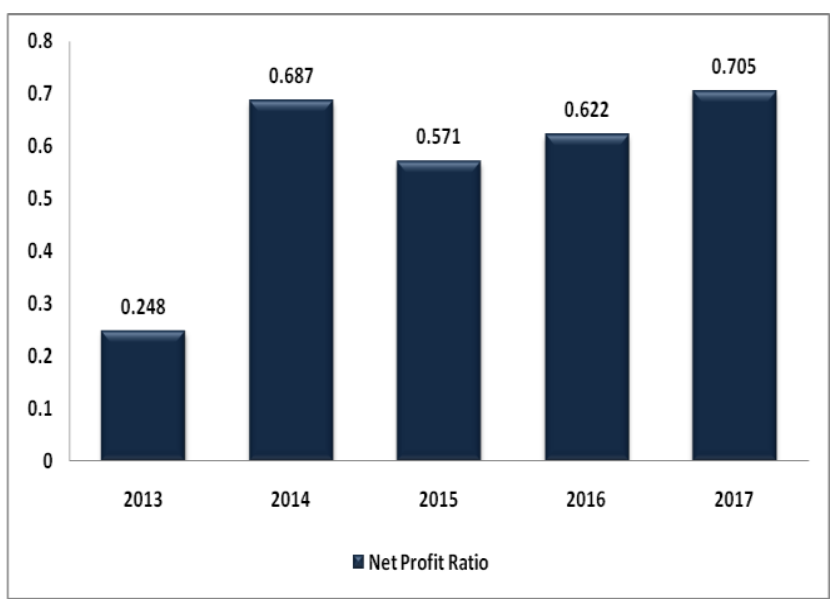

Fig: 3 NET PROFIT RATIO

TABLE 4 GROSS PROFIT RATIO

\begin{tabular}{|l|l|l|l|}
\hline Years & Gross Profit & Net Sales & Gross Profit Ratio \\
\hline 2013 & $30,854,152.38$ & $124,612,231.32$ & 0.248 \\
\hline 2014 & $102,250,057.89$ & $148,745,150.78$ & 0.688 \\
\hline 2015 & $81,117,232.38$ & $142,008,057.06$ & 0.572 \\
\hline 2016 & $92,429,095.13$ & $148,703,146.00$ & 0.622 \\
\hline 2017 & $104,283,901.36$ & $147,856,830.33$ & 0.706 \\
\hline
\end{tabular}

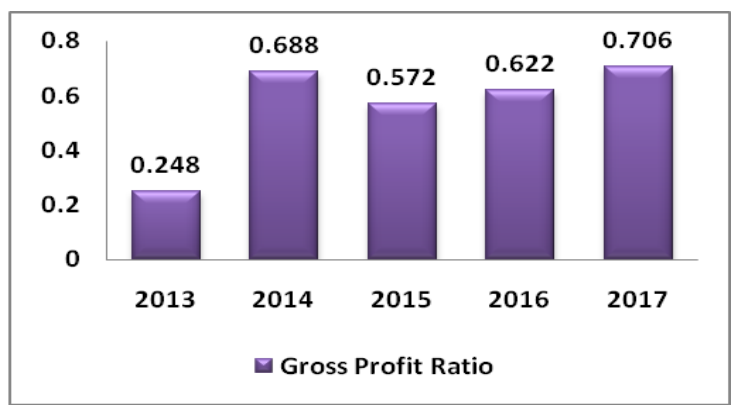

Fig:4 GROSS PROFIT RATIO

TABLE 5 EXPENSES RATIO

\begin{tabular}{|l|l|l|l|}
\hline Years & Total Expenses & Net Sales & Expenses Ratio \\
\hline 2013 & $98,484,416.21$ & $124,612,231.32$ & 0.79 \\
\hline 2014 & $51,333,109.93$ & $148,745,150.78$ & 0.35 \\
\hline 2015 & $65,746,075.79$ & $142,008,057.06$ & 0.46 \\
\hline 2016 & $60,930,728.84$ & $148,703,146,00$ & 0.41 \\
\hline 2017 & $51,370,565.77$ & $147,856,830.33$ & 0.35 \\
\hline
\end{tabular}

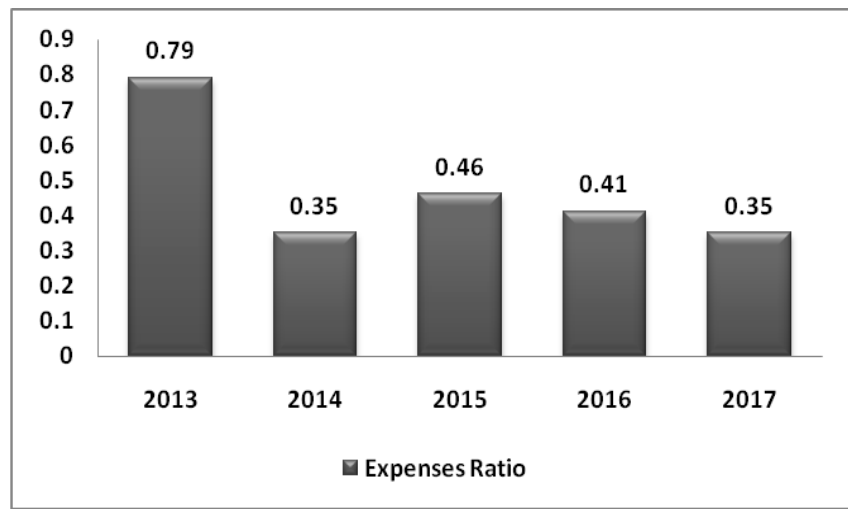

Fig 5 CHART SHOWING EXPENSES RATIO

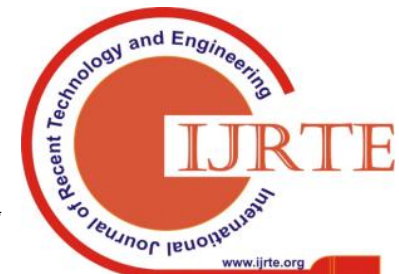


TABLE 6 TREND ANALYSIS OF CURRENT ASSETS

\begin{tabular}{|l|l|l|l|l|l|l|}
\hline Years & $\mathrm{X}$ & $\mathrm{Y}$ & $\mathrm{X}^{2}$ & $\mathrm{XY}$ & Trend Value & Deviation \\
\hline 2013 & -2 & 56132794.31 & 4 & -112265589 & -57860024.76 & 113992819.1 \\
\hline 2014 & -1 & 78987183.77 & 1 & -78987183.8 & -8725117.2 & 87712300.97 \\
\hline 2015 & 0 & 99628120.40 & 0 & 0 & 40409790.36 & 59218330.04 \\
\hline 2016 & 1 & 119900229.51 & 1 & 119900229.5 & 89544697.92 & 30355531.59 \\
\hline 2017 & 2 & 136700747.36 & 4 & 273401494.7 & 138679605.5 & -1978858.14 \\
\hline T0TAL & & 491349075.35 & 10 & 202048951.8 & & \\
\hline
\end{tabular}

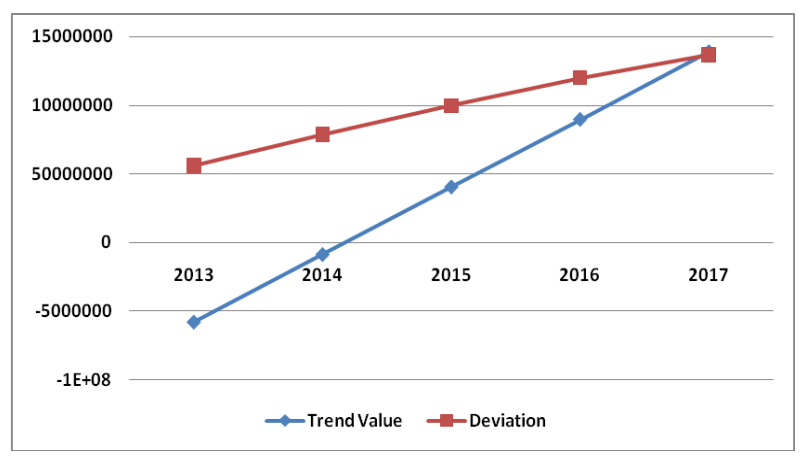

Fig:6 TREND VALUE OF CURRENT ASSETS

\section{TABLE 7 PROJECTED TREND VALUE - CURRENT ASSETS FOR THE FORTHCOMING YEARS (2017 to 2021)}

\begin{tabular}{|l|l|}
\hline YEAR & FUTURE TREND (Trend value + B) \\
\hline 2017 & 138679605.5 \\
\hline 2018 & 187814513.1 \\
\hline 2019 & 236949420.6 \\
\hline 2020 & 286084328.2 \\
\hline 2021 & 335219235.7 \\
\hline
\end{tabular}

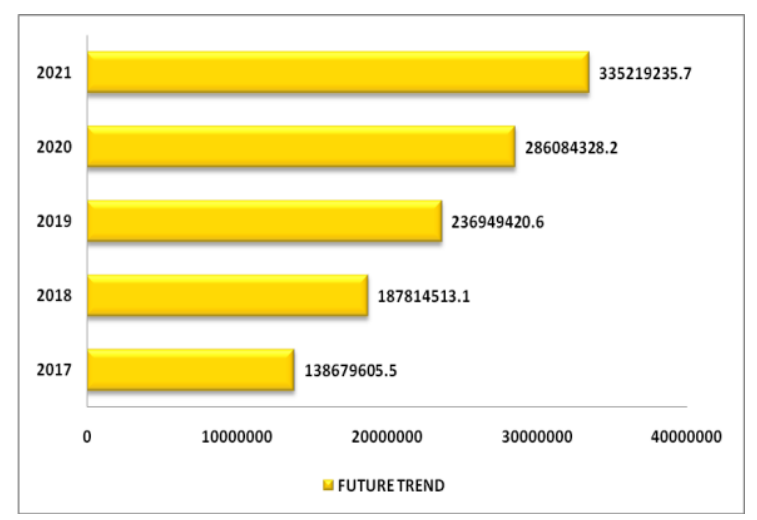

Fig: 7 CHART SHOWING TREND ANALYSIS OF CURRENT ASSETS

\section{V.RESULTS}

The working capital statement of VJ Engineers for the year 2016 and 2017 showsCurrent assets of the company an increasing trend from the year 2016-2017. Current liabilities increased from 2016 2017. This results in a decrease in working capital

$\checkmark \quad$ The working capital statement of VJ Engineers for the year 2015 and 2016 showsCurrent assets of the company an increasing trend from the year 2015-2016. Current liabilities increased from 2015 2016. This results in an increase in working capital

$\checkmark \quad$ The working capital statement of VJ Engineers for the year 2014 and 2015 showsCurrent assets of the company an increasing trend from the year 2014-2015. Current liabilities increased from2014-2015. This results in a decrease in working capital[25],[27],[29]

$\checkmark \quad$ The working capital statement of VJ Engineers for the year 2013 and 2014 showsCurrent assets of the company an increasing trend from the year 2013-2014. Current liabilities increased from 2013-2014. This results in a decrease in working capital

$\checkmark \quad$ The current ratio in 2013 and 2014, the current asset ratio was 7.08 and 9.09 respectively. But it started decreasing in the consequent years to 1.29 in 2016 , 1.39 in 2017

$\checkmark \quad$ The liquid ratio for the year 2013 was 3.35 , and in 2017 it was 0.85 . This sudden fall is due to the increase in current liabilities

$\checkmark \quad$ In the year 2013, the cash position ratio was 3.35 and it increased in 2014 and 2015 but meet a sudden fall during 2016 and 2017 as 0.76 and 0.85

$\checkmark \quad$ In the year 2013, the net profit ratio was 0.248 and it is increasing thereafter

$\checkmark \quad$ In the year 2013, the gross profit ratio was 0.248 and it is increasing thereafter

$\checkmark \quad$ In the year 2013, the expenses ratio was 0.79 and it is decreasing year on year showing a favourable sign for the company

$\checkmark$ In the year 2013, this ratio was 0.25 and it is increasing from then every year showing a good sign for the company

$\checkmark \quad$ In the year 2013, the stock turnover ratio was 4.22 and is decreasing gradually from then

$\checkmark \quad$ In the year 2013, debtor turnover ratio was 6.82 and it is decreasing gradually from then

$\checkmark \quad$ In the year 2016, creditor turnover ratio was 4.50 and in 2017 it is 6.14

$\checkmark$ The working capital of the company shows the increasing trend in 2013, 2014 and 2015 but meets a sudden fall in 2016 and 2017 due to increased current liability proportionate to current assets

$\checkmark \quad$ In the year 2013, the working capital turnover ratio was 2.59 and it is highly volatile

$\checkmark \quad$ In the year 2013, working Capital to fixed Assets ratio was 3.02 and it showed an increasing trend up to 2015 but meets a sudden fall during 2016 and 2017 reaching 1.67 in 2017

$\checkmark \quad$ In the year 2015, the ROI percentage is 2.41 and it increased in 2017 as $2.83 \%$. Showing a good sign of returns to the company in its investments

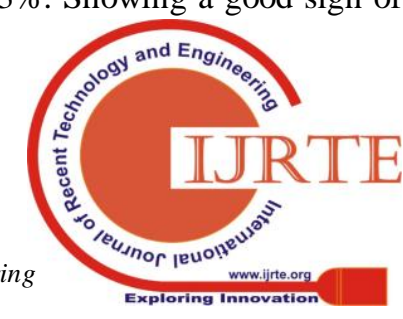


$\checkmark \quad$ The trend analysis for the above years shows only a marginal increase. This is mainly due to the reason that these data's have been arrived in comparison with the last 5 years current assets value. There was no phenomenal increase in growth in term of assets during 2018 and this is the one of the major reasons that the projections are also showing only a marginal increase. In reality if we assume that the same increasing in trend continues compared to 2017, the ratio for the above five years will be still higher.

\section{DISCUSSION}

The organization should focus to keep up the liquidity position on money equalization and attempt to prepare assets from banks/monetary foundations. [26],[28],[30]

$\square$ Bring extra working capital as far as long haul reserves. This cash ought to be utilized to reimburse sundry leasers and improve the present proportion.

$\square$ The organization is prescribed to assemble assets from different sources might be outer or structure inside.

$\square$ The organization can get long haul assets either by method for value and use it to fortify the working capital. [31],[33],[32]

\section{Creditors ought to be paid in time.}

$\square$ In request to maintain a strategic distance from awful obligations the organization should charge enthusiasm on the sum not paid on the due date.

$\square$ Frequent alterations ought to be done on the different plans and arrangements.

$\square$ The organization can limit credit to clients who constantly make default in their installments. This will empower the organization to pay off its awful obligations.

Well prepared and productive Field Sales Staff (FSS) can be named and they will be remunerated as it propels them to even out genuine and evaluated accumulations.

$\square$ The inactive working capital ought to be completely used by decreasing the working cycle to a base level.

$\square$ The organization builds the agreement receipts volume. So as results in ideal use of limit and amplification of benefit.

Cost control systems are to be embraced on the organization any place conceivable.

Company can use the stores and surplus by either underwriting or contribute the cash some place a venture to get advantage.

\section{CONCLUSION}

The suggestions have been advanced to the board for its thought. Despite the fact that the proposals are done dependent on the projections of the verifiable information accessible for the books of records, the Management of VJ Engineers needs to take endeavors to actualize the vital strides by investigating the money related execution of the past year.Actually, a fruitful budgetary official is intrigued not in keeping up a decent present proportion but rather in keeping up a movable record of current resources so the business may work easily. Subsequently the working capital ideas are progressively essential to the administration so as to keep up the present resources and current liabilities. The organization has ideal net resources worth, deals and salary of the organization likewise is in expanding pattern. The organization has ideal Earnings before premiums and assessments, income. Income per offer worth are expanding each year.Price per deals proportion and Price per Earnings proportion are bit by bit diminishing. The lower the PSR worth is the better.

The market products worth and deals products worth are in expanding pattern. This demonstrates the organization is one of the real players in the market just as in the business. Executive's advantage worth is additionally expanding drastically.Working capital keep up by the organization is insufficient and the consumption of that organization likewise exceptionally high. Deficient working capital will prompt need liquidity position of the company.Cash and bank adjusts are high. The organization ought to keep up this level in the progressive years. To end with, if the organization takes the above activities proposed, the organization would continue as the pioneer in the vitality business, with its past records.

\section{REFERENCES}

1. G BharthVajan R., Ramachandran S.,Psychographic dimensions of training,2016,International Journal of Pharmacy and Technology,V-8,I-4,P-23727-23729

2. Balakrishnan P., Bharthvajan R.,A study on human resource planning in hospitals in Chennai City,2014,International Journal of Applied Engineering Research,V-9,I-22,P-7503-7507

3. Priyadarsini P., Bharthvajan R.,Role of emotional intelligence training programme in reducing the stress of the nurses,2014,International Journal of Applied Engineering Research,V-9,I-22,P-7411-7421

4. Kerinab Beenu G., Bharthvajan R.,Empirical analysis on the cosmetic buying behavior of young women in South India,2014,International Journal of Applied Engineering Research,V-9,I-22,P-7361-7366

5. Balakrishnan P., Bharthvajan R.,Whistling in the wind,2014,International Journal of Applied Engineering Research,V-9,I-22,P-7586-7593

6. Krishnan B., Peter M.,Health hazards of Indian Bpo employee-an alarming issue,2014,International Journal of Applied Engineering Research,V-9,I-22,P-7336-7341

7. Kerinab Beenu G.H., Peter M.,Role of insurance in economic development,2014,International Journal of Applied Engineering Research,V-9,I-22,P-7532-7539

8. Balakrishnan P., Peter M., Priyadarsini P.,Efficiency of safety measures for wellbeing of employees in manufacturing industry,2014,International Journal of Applied Engineering Research,V-9,I-22,P-7376-7382

9. Anbarasi M., Praveen Kumar S.,Online sales promotions of herbal products and its effectiveness towards tanisha.com,2019,Indian Journal of Public Health Research and Development,V-10,I-1,P-195-200

10. Anbarasi M., Praveen Kumar S.,Various online marketing and promotions strategies to improve the 
validation towards the organic products in the pharmaceutical sectors,2019,Indian Journal of Public Health Research and Development, V-10,I-1,P-263-269

11. Loganathan R., Praveen Kumar S.,Grievance handling a key factor for solving issues of employees in an organization,2014,International Journal of Applied Engineering Research,V-9,I-22,P-7483-7491

12. Loganathan R., Praveen Kumar S.,Study on preference of private label brands in super and Hypermarkets,2014,International Journal of Applied Engineering Research,V-9,I-22,P-7327-7335

13. Smitha M., Praveen Kumar S.,Understanding stress and its managementamong the nurses in Chennai city,2014,International Journal of Applied Engineering Research,V-9,I-22,P-7560-7565

14. Kerinab Beenu G.H., Praveen Kumar S.,A study on the investment behavior of Chennai investors in mutual fund schemes,2014,International Journal of Applied Engineering Research,V-9,I-22,P-7520-7525

15. Loganathan R., Praveen Kumar S.,Retention strategies key for organizational productivity,2014,International Journal of Applied Engineering Research,V-9,I-22,P-7443-7447

16. Pavithra J., Ganesan M., Brindha G.,State wise analysis of microfinance sector in India,2016,International Journal of Pharmacy and Technology,V-8,I-4,P-23417-23432

17. Pavithra J., Ganesan M.,A comparative study on microfinance in India and abroad,2016,International Journal of Applied Business and Economic Research,V-14,I-8,P-5471-5476

18. Pavithra J., Ganesan M.,A study on awareness and impact of micro-financial schemes,2016,International Journal of Applied Business and Economic Research,V-14,I-8,P-5449-5460

19. Senthilmurugan P., Pavithra J.,Consumer preference towards organised retailing with reference to Big Bazaar,2014,International Journal of Applied Engineering Research,V-9,I-22,P-7469-7475

20. Senthilmurugan P., Pavithra J.,Implication of social media marketing in growing healthcare industry,2014,International Journal of Applied Engineering Research,V-9,I-22,P-7448-7456

21. Loganathan R., Pavithra J.,Consumer perception towards private label brand over other brands in super markets and hypermarkets,2014,International Journal of Applied Engineering Research,V-9,I-22,P-7355-7360

22. Kerinab Beenu G., Pavithra J.,Tradeâ€"off between liquidity and profitability in logistics industry,2014,International Journal of Applied Engineering Research,V-9,I-22,P-7398-7401

23. Kerinab Beenu G., Pavithra J.,A study on the prospective consumerâ€ $€^{\mathrm{TM}_{\mathrm{S}}}$ perception towards utility cars in Chennai city,2014,International Journa of Applied Engineering Research,V-9,I-22,P-7526-7531

24. Pavithra J., Dilli Babu P., Ambuli T.V.,A study on budgetary control at Maruti Service Masters, Chennai,2014,International Journal of Applied Business and Economic Research,V-12,I-2,P-151-161

25. Pavithra J., Dilli Babu P., Ambuli T.V.,A study on customer satisfaction of retro Garments Pvt Ltd, Chennai,2014,International Journal of Applied Business and Economic Research,V-12,I-2,P-381-391

26. Kerinab Beenu G.H., Pavithra J., Senthilmurugan P.,A study on the influence of promotional activities for TATA ARIA among consumers in Chennai,2014,International Journal of Applied Engineering Research,V-9,I-22,P-7572-7578

27. Vijayaragavan S.P.,An investigative expert that's general FBG sensors, International Journal of Mechanical Engineering and Technology,V-8,I-8,PP-1500-1505,Y-2017

28. Vijayaragavan S.P.,Equalization routing protocol for Wi-Fi sensor strategy,International Journal of Mechanical Engineering and Technology,V-8,I-8,PP-1662-1666,Y-2017

29. Karthik B., Kiran Kumar T.V.U., Vijayaragavan P., Bharath Kumaran E.,Design of a digital PLL using 0.35 $\hat{\mathrm{I}}^{1 / 4 \mathrm{~m}}$ CMOS technology,Middle East Journal of Scientific Research,V-18,I-12,PP-1803-1806,Y-2013

30. Kanniga E., Selvaramarathnam K., Sundararajan M.,Kandigital bike operating system,Middle - East Journal of Scientific Research,V

31. Jasmin M., Vigneshwaran T., Beulah Hemalatha S.,Design of power aware on chip embedded memory based FSM encoding in FPGA,International Journal of Applied Engineering Research,V-10,I-2,PP-4487-4496,Y-2015

32. Jasmin M.,Optimization techniques for low power VLSI circuits,Middle East Journal of Scientific Research,V-20,I-9,PP-1082-1087,Y-2014

33. Jasmin M., Vigneswaran T.,Fuzzy controller for error control of on - Chip communication,2017 International Conference on Algorithms, Methodology, Models and Applications in Emerging Technologies, ICAMMAET 2017,V-2017-January,I-,PP-1-5,Y-2017

\section{AUTHORS PROFILE}

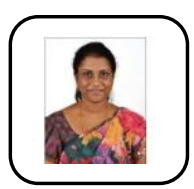

CS. Gowtham ,Assistant Professor ,Department of MBA, Bharath Institute of Higher Education and Research, Tamilnadu, India

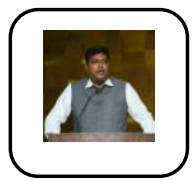

Dr.S.Praveen Kumar Professor ,Department of MBA Bharath Institute of Higher Education and Research, Tamilnadu, India

Dr.A.Kamal Associate Professor ,Department of EEE, Bharath Institute of Higher Education and Research, Tamilnadu, India 